\title{
Phytochemical and biochemical compostion of wild honey a case study in Estern zone areas in tigray Ethiopia
}

\begin{abstract}
The study was carried out to evaluate the phytochemical and biochemical composition of wild honey available in different were das of eastern zone of Tigray. The Moisture and ash contents of the samples had average values of $16.00 \pm 2.19 \mathrm{~g} / 100 \mathrm{~g}$ and $0.47 \pm 0.09 \mathrm{~g} / 100 \mathrm{~g}$, respectively. The protein contents ranged between 0.35 and $1.08 \mathrm{~g} / 100 \mathrm{~g}$ with a mean of $0.67 \pm 0.25 \mathrm{~g} / 100 \mathrm{~g}$ while fat content lied between 0.10 and $0.50 \mathrm{~g} / 100 \mathrm{~g}$ with a mean of $0.29 \pm 0.11 \mathrm{~g} / 100 \mathrm{~g}$. Total carbohydrate contents and Energy values showed average values of $82.30 \pm 2.03 \mathrm{~g} / 100 \mathrm{~g}$ and $1,401.33 \pm 33.71 \mathrm{KJ} / 100 \mathrm{~g}$, respectively. Fructose contents have an average of $38.94 \pm 0.90 \mathrm{~g} / 100 \mathrm{~g}$, while glucose contents had a mean value of $31.65 \pm 2.79 \mathrm{~g} / 100 \mathrm{~g}$. The sucrose contents of the honey samples had a mean value of $1.84 \pm 0.79 \mathrm{~g} / 100 \mathrm{~g}$. Total polyphenols and vitamin $\mathrm{C}$ contents showed mean values of $65.31 \pm 19.50 \mathrm{mg}$ Gallic Acid Equivalent (GAE)/100 $\mathrm{g}$ and $21.15 \pm 3.99 \mathrm{mg} / 100 \mathrm{~g}$, respectively. The results of this study indicate that the samples compare favorably with samples in many parts of the world and also fall within the limits of international standards. Due to this high honey production potential of the study area for apiculture and good quality standard of honey, it is advised to exploit the potential for export market with better intervention.1 More study is also required to characterize the honeybees of the area and major pests and diseases of economic importance.
\end{abstract}

Keywords: photochemical, chemical composition, wild honey
Volume 4 Issue 3 - 2017

\section{TG Amabye}

Department of chemistry, Mekelle University, Ethiopia

Correspondence: TG Amabye, Department of chemistry, College of Natural Science and computional, Mekelle University, Ethiopia, PO Box 23I, Email teklitgeb@gmail.com

Received: February 26, 2016 | Published: May 05, 2017

\section{Introduction}

Honey has a long history of human consumption, and is most commonly consumed in its unprocessed state (i.e. liquid, crystallized or in the comb). It is taken as medicine, eaten as food, or incorporated as an additive in a variety of food and beverages. In Ethiopia, honey is primarily used to produce the country's national drink Tee, a traditional honey wine or mead (http://www.ethiopia-ciafs.org/). Carbohydrates cover more than half the composition of honey, while the second greatest component is water and minor quantities of proteins, ashes, amino acids and vitamins are also a constituent of honey. ${ }^{2}$ Because variation of origin of the flora or the nectar of the flower that the bee utilized, the composition as well as the characteristics of Honey showed variation in its physical and chemical properties such as $\mathrm{pH}$, enzymes activities, ash contents, electrical conductivity and hydroxyl methyl furfural. Honey is different from others because of its tendency of forming granules, In its content, sugars are the main ingredients of its dry matter, and its concentration also contribute to the high density, high viscosity, immunity from spoilage and moisture absorbance nature of honey.

Ethiopia is the largest honey producer in Africa and the 10th largest in the world. The total amount of honey production in the country is estimated to be more than 43,000 metric tons per year. But about $80 \%$ of the total honey produced goes to preparation of well-known traditional alcoholic drink: Tee. Due to the presence of diverse flora and fauna, each region of Ethiopia produces a unique variety of honey. The white honey from Tigrai, Tebeb (Tigrigna), is produced in localities where blossoms of Beciumgrandiflorum are found in abundance. The white honey of Sidamo is from the
Geteme flowers (Scheffleraabyssinica). Other honey producing trees and shrubs include: Vernoniaamygdalina (Grawa), Eucalyptus globules (BahirZaf), Opuntiaficus-indica (Qulqwal), Cordiaafricana (Wanza), Syzygiumguineense (Dokma), Hagenia abyssinica (Koso), Acacia Senegal (Sbansa-Grar), etc. These plants are recommended for planting to increase Ethiopia's honey production. Honey is a sweet and viscous product made by bees after ingesting the nectar of flowers. It comprises mainly carbohydrates, fructose and glucose, which together make up nearly $70 \%$, followed by about $20 \%$ water, and small amounts of an array of substances such as sucrose $(0-2 \%)$, and traces of heavy metals, proteins $(0.3 \%)$, ascorbic acid, flavonoids, enzymes, vitamins, etc. There is more fructose $(38 \%)$ than glucose $(31 \%)$ in honey, while sucrose, which is dominant in sugar cane, is found in honey only in trace amounts.

Compared to water, honey has high refractive index (about 1.5) and high viscosity. This is because it is almost like concentrated sugar solution. Its specific gravity is also 1.4, a characteristic of honey that can be used in quality control. Its color also varies from light brown to dark depending on the nectar the bees feed on, season and production details such as if heat is used during processing etc. Heating honey accelerates production of undesirable substances. Another interesting phenomenon is the fact that honey is quite acidic with an average $\mathrm{pH}$ of 4 . We sometimes fail to notice its relative strong acidic nature because its high sugar content masks its acidity. Gluconic acid (2, 3, 4, 5, 6-pentahydroxyhexanoic acid) is the main acid followed by acetic, butyric, citric, formic, lactic, malic, oxalic and succinic acids. The quality of honey gradually deteriorates on long standing, poor storage conditions and warm temperature. 
This is because carbohydrates, in particular fructose, gradually degrade to HMF (5-hydroxymethylfurfural). High HMF content indicates honey of poor quality. The European Union (EU Directive $110 / 2001$ ) considers honey with HMF greater than $80 \mathrm{mg} / \mathrm{kg}$ as hazardous to health. ${ }^{5}$ African countries that intend to export honey should develop capacity to monitor levels of this and other honey constituents.

Within Africa, Ethiopia is the largest producer of honey. Ethiopia, having the highest number of bee colonies and surplus honey sources of flora, is the leading producer of honey and beeswax in Africa. On a world level, Ethiopia is fourth in beeswax and tenth in honey production. From 2005-2010, Ethiopian honey production increased $26 \%$ from 36,000 MTs to 45,300MTs; (http://www.ethiopia-ciafs. org/). Ethiopia produces dozens of honey varieties based on pollen source, season, and agro ecological region of production. These all factors also determine production and harvest cycles. ${ }^{6}$ Honey consistency and color range from white varieties that are butterycreamy or sandy-sugary, to red varieties that are tart and acidic, with aromatic amber and yellow varieties in between. The white, grainy honey from Tigray, the most northern region of Ethiopia, is made from a local blossom of the sage plant family, known as labiate, which gives it its unusual color. ${ }^{7,8}$

The regional state of Tigray is running a powerful development program in beekeeping and its productsso that poor crop production zones of the region are involved mainly in beekeeping interventions to maintain food security and to empowering higher production at first to satisfy family needs as well as to meet the requirements of both domestic and international market. ${ }^{9}$ The aim of the present study was study to estimate the honey quality parameters versus botanical origin via conducting the physico-chemical analysis of the eastern zone Tigray. ${ }^{10,11}$

\section{Materials and methods}

\section{Sample collection and preparation}

Tigray region is the northern most of the nine regional states of Ethiopia. Its capital is Mekelle. Tigray is bordered by Eritrea to the north, Sudan to the west, the Afar region to the east, and the Amhara region to the south and southwest. Besides Mekelle, other major cities in Tigray includes AbiyAddi, Adigrat, Adwa, Axum, Humera, Korem, May chew, Qwiha, Shire (India Selassie), Wukro and Zalambessa, as well as the historically significant town of Yeha. ${ }^{12}$

Based on figures from the Central Statistical Agency (CSA) of Ethiopia published in 2014, Tigray has an estimated total population of $5,055,999$, consisting of $2,491,999$ men (49.3\%) and 2,564,000 women $(50.7 \%)$. About $3,792,000$ or $75 \%$ of the population are estimated to be rural inhabitants, while $1,264,000$ or $25 \%$ are urban(CSA 2013). With an estimated area of 50,078.64 square kilometers, this region has an estimated density of 86.56 people per square kilometer.

Honey samples were collected from the market indifferent were das of the eastern zone of tigray. All the fresh samples were collected in sterile condition using a container labeled with numbers, place and date of collection and stored at ambient temperature (Figure 1).

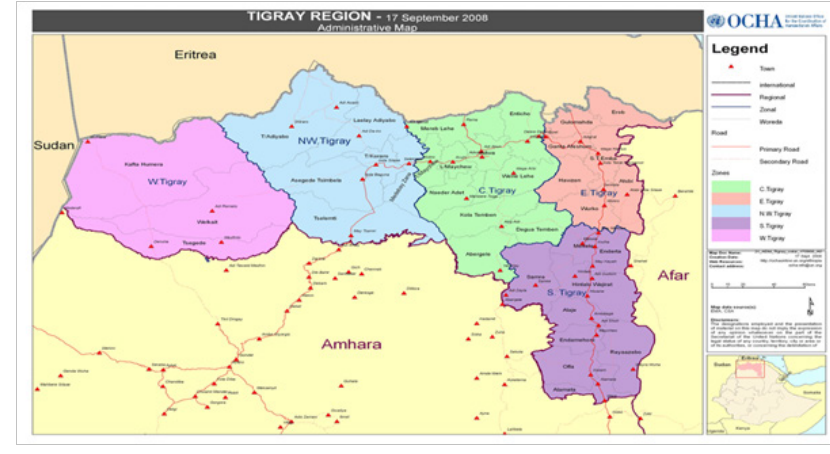

Figure I Tigray region.

\section{Biochemical analysis}

\section{Determination of phytochemical analysis}

The qualitative and quantitative screening test for phytochemicals wild honey samples were carried out. ${ }^{13}$

\section{Determination of total phenolic content}

The phenolic compounds (flavonoids and phenolic acids) were extracted from the honey samples according to the method described by Kacaniova. ${ }^{14}$ Ten grams $(10 \mathrm{~g})$ of the honey sample was dissolved in $50 \mathrm{~mL}$ of acidified distilled water (acidified to $\mathrm{pH} 2$ with $\mathrm{HCl}$ ). The solution filtered with a cotton filter to remove solid particles and the filtrate was used for the estimation of its total phenolic compounds. The total phenolic content was estimated using the FolinCioucalteu colorimetric method. ${ }^{15}$ Appropriately diluted, $0.2 \mathrm{~mL}$ of $10 \%$ aqueous extract of the honey sample was treated with $0.8 \mathrm{~mL}$ of the Folin-Cioucalteu reagent and $2.0 \mathrm{~mL}$ of $7.5 \% \mathrm{Na}_{2} \mathrm{CO}_{3}$ and mixed thoroughly. The mixture was diluted using $7.0 \mathrm{~mL}$ distilled water and the absorbance was read after $2 \mathrm{hrs}$ at $765 \mathrm{~nm}$; the result was calculated as gallic acid equivalent. ${ }^{16}$

\section{Determination of proximate composition}

Proximate compositions of the honey samples were determined using the methods of AOAC. ${ }^{17}$

\section{Determination of reducing sugars and sucrose contents}

The concentration of reducing sugar and sucrose in wild honey sample was determined by Layne-Enyon titration method as described in AOAC. ${ }^{18}$

\section{Determination of glucose}

Glucose content of the honey samples was determined by enzymatic oxidation with glucose oxidase reagent (Randox Laboratories Ltd., UK). Twenty micro liters $(20 \mu \mathrm{L})$ of the sample or standard was allowed to react with $2.0 \mathrm{~mL}$ of the reagent, mixed well and incubated for $10 \mathrm{~min}$ at $37^{\circ} \mathrm{C}$. The absorbance of the sample (A mple $)$ and standard $\left(\mathrm{A}_{\text {standard }}\right)$ was read against a reagent blank within $60 \mathrm{~min}$. Glucose concentration was calculated as follows: 
Glucose content $(\mathrm{mg} / \mathrm{dL})=\left(\mathrm{A}_{\text {sample }} / \mathrm{A}_{\text {standard }}\right) \mathrm{xConc}$. of standard $=(\mathrm{A}$ sample $\left./ \mathrm{A}_{\text {standard }}\right) \times 100(\mathrm{mg} / \mathrm{dL})$

\section{Determination of fructose content}

Fructose content was determined using the resorcinol reagent method. ${ }^{19}$

\section{Statistical analysis}

The data obtained in the study were analyzed statistically using ANOVA and student t-test (using GraphPadInstat Statistical Program). Differences between mean values were considered significant at values of $\mathrm{P}<0.05$.

\section{Results and discussion}

The qualitative study of phytochemicals showed that the honey samples were composed of tannins, phlobatanins, flavonoids, terpenoids, glycosides, saponins, alkaloids and fluorides.

Table 1 showed that the maximum concentration of Saponins $(3.49 \pm 0.07)$ was found in kilteawlaelo, while minimum concentration $(2.11 \pm 0.04)$ in Europe. The maximum concentration of Alkaloid $(0.18 \pm 0.07)$ was found in Gantafeshumhoney, while minimum concentration $(0.14 \pm 0.02)$ in wukro. It has been reported that due its toxic nature honey containing alkaloids may not have a significance medicinal value ${ }^{20}$ the maximum concentration of fluoride $(0.25 \pm 0.06)$ was found in astbi while minimum concentration $(0.11 \pm 0.03)$ in wukro.

In addition to this it is shown that the maximum concentration of tannin $(0.54 \pm 0.04)$ was found in Adigrat while minimum concentration $(0.34 \pm 0.03)$ in sinkata honey. The maximum concentration of phlobatanin $(0.76 \pm 0.05)$ was found in Gantafeshum while minimum concentration $(0.65 \pm 0.09)$ in astbi. The maximum concentration of flavonoids $(0.36 \pm 0.08)$ was found in kilteawlaelo, while minimum concentration $(0.27 \pm 0.05)$ in Astbi. The maximum concentration of Terpenoids $(0.45 \pm 0.06)$ was found in Europe, while minimum concentration $(0.33 \pm 0.05)$ in wukro honey. The maximum concentration of glycoside $(0.47 \pm 0.06)$ was found in Gantafeshum while minimum concentration $(0.31 \pm 0.08)$ in wukro wild honey. The maximum concentration of Saponins $(3.49 \pm 0.07)$ was found in Kilteawlaelo while minimum concentration $(2.11 \pm 0.04)$ in Europe The maximum concentration of Alkaloid $(0.18 \pm 0.02)$ was found in Gantafeshum were the while minimum concentration $(0.12 \pm 0.06)$ in sinkata. The maximum concentration of fluorides $(0.25 \pm 0.04)$ was found in Astbi while minimum concentration $(0.11 \pm 0.03)$ in wukro honey.

The minimum, maximum and average moisture contents of the honey on different hive type and honey source analyzed in the present study are indicated in Table 2 . Honey moisture is the quality criterion that determines the capability of honey to remain stable and to resist spoilage by yeast fermentation: the higher the moisture, the higher the probability that honey will ferment upon storage. Lower moisture limits (e.g. 19\%), ensuring a better shelf -life of honey which would be met by a large majority of the commercial honeys, have been proposed by some countries for the revision of the Codex Alimentations. The overall mean moisture content of the study area's honey was lower than the country's average (20.6\%) for moisture content of honey reported by Adgaba. ${ }^{21}$ According to honey standards set by the Ethiopian Quality and Standards Authority, the moisture content of the study area's honey falls under the Grade 'A' category. ${ }^{22}$ The maximum acceptable limit for moisture content of Ethiopian honey is $23 \%,{ }^{21}$ while the maximum acceptable moisture content of honey reported by the International Honey Commission is $20 \% .^{23,24}$ The low moisture content of the examined honey samples is important and affects quality. Moulds and yeasts cause deterioration of the quality of honey when the moisture content is high, especially if it is $>19 \%$. The moisture content of honey depends on various factors such as the harvesting season, the degree of maturity that honey reached in the hive, type of hive used and environmental temperature. The moisture content of honey samples obtained from modern hives was significantly $(p<0.001)$ higher than honey collected from traditional hives. The variation observed in moisture content among honey samples obtained from the two hive types may be due to the difference in bee-hive handling practiced by the beekeepers. The low moisture content of honey obtained from traditional hives may be associated with a hive type that allowed loss of moisture from honey by evaporation. No significant moisture content differences $(p>0.05)$ were observed between honey samples obtained from the different locations (Table 2).

The Ash content of honey is also a parameter that is used in determining the floral origin of honeys. Thus, by reference to the Codex Alimentarius Standards, all the honeys analyzed in this study correspond to nectar honey since their ash contents falls within the values of $<0.6 \%$. The ash contents of honeys represent their mineral and trace element contents. According to Bogdanov, ${ }^{25}$ blossom honeys have a mineral content mostly between 0.1 and $0.3 \%$ while that of honeydew honeys can reach $1.0 \%$ of the total. Several investigations have shown that the trace element content of honey depends mainly on the botanical origin of honey; i.e. light blossom honeys have low contents than dark honeys such as honeydew, chestnut and heather honeys..$^{26,27}$

The protein contents of honey samples from some of the States of the northeast were significantly $(\mathrm{P}<0.05)$ different. The values obtained in this study are similar to those reported by Khalil, ${ }^{28}$ for five different brands of unifloral honey from the northern region of Bangladesh, which ranged between 0.655 and $0.744 \mathrm{~g} / 100 \mathrm{~g} .{ }^{29}$ The amount of nitrogen in honey is generally low, in average about $0.04 \%$ although it may reach up to $0.1 \%{ }^{17,30}$ It was also reported that of the total amount of Nitrogen in honey only $40-65 \%$ is in protein, the remaining part of the Total nitrogen resides in substances other than protein, such as amino acids. About 8 to 11 proteins have been found in various honeys but only four (4) proteins are common to all honeys and these four (4) proteins appear to originate from the honey bee rather than from nectar. The honey proteins are mainly in the form of enzymes..$^{30}$ The honey bees add different enzymes during the process of honey ripening. The enzymes added include diastase (amylase), which digest starch to maltose and is relatively stable to heat and storage, and invertase (saccharase or $\alpha$-glucosidase), which catalyzes the conversion of sucrose to glucose and fructose. The invertase also catalyzes many other sugar conversions and is mainly responsible for the sugar patterns of honey. Glucose oxidase and catalase are the two enzymes added by the honey bee to regulate the production of hydrogen peroxide $\mathrm{H}_{2} \mathrm{O}_{2}$; the $\mathrm{H}_{2} \mathrm{O}_{2}$ serve as one of the anti-bacterial factor in honey.

The significant differences observed between the total protein contents of honey samples from some of the States within the subregion may be ascribed to differences in the botanical origin of honey 
since it was reported that the diastase and the invertase enzymes varied in wide limits depending on the botanical origin of honey. ${ }^{31}$ Bosi et al. ${ }^{32}$ had reported protein contents of honey varying between 0.01 to $0.04 \mathrm{~g} / 100 \mathrm{~g}$ with proline, lysine, phenylalanine, aspartic acid and glutamic acid as the most widely detected amino acids.

The fat contents of the honey samples investigated in this study fall within the range of 0.1 to $0.5 \mathrm{~g} / 100 \mathrm{~g}$. as the report indicates that the honey samples contains little or no fat ,however the presence of free fatty acids like palmitic, oleic and linolenic acids have been reported in white clover honey. In a biochemical analysis of five different brands of unifloral honey available in the northern region of Bangladesh, Khalil ${ }^{28}$ reported total fat contents in the range of 0.134 to $0.146 \mathrm{~g} / 100 \mathrm{~g}$; thus, indicating that honey contains very little amount of lipid and therefore not considered a good source of lipid.

The total carbohydrate contents of the honey samples from all the States were not significantly different from each other; this corresponds to the findings of others scientists. ${ }^{28,33,34}$ Carbohydrates are the main constituents of honey comprising about $95 \%$ of honey dry weight. The monosaccharides, fructose and glucose, are the main sugars found in honey; these hexoses are products of the hydrolysis of sucrose. In addition to these sugars, 25 others have been detected in honey samples. ${ }^{4,35}$ The principal oligosaccharides in blossom honey include Table I Quantitative test for photochemical honey samples the disaccharides sucrose, maltose, turanose, erlose, etc. On the other hand, honeydew honeys also contain the disaccharides melezitose and raffinose; with trace amounts of tetra and pentasaccharides also isolated. ${ }^{17}$

The average energy value of the honey samples from all the States ranged between $1383.23 \pm 39.09$ and $1410.20 \pm 24.43 \mathrm{KJ} / 100 \mathrm{~g}$. Honey is primarily a high energy carbohydrate food and the sugars are easily digestible sugars similar to those found in many fruits (White and Doner, 1980). For this reason honey is regarded as a good food for both infants and adults. Blasa ${ }^{36}$ had reported caloric value of about $303 \mathrm{kcal} / 100 \mathrm{~g}$ of honey.

The reducing sugar contents of the samples used in this study had average value of $72.40 \pm 6.65 \mathrm{~g} / 100 \mathrm{~g}$, the values obtained in this study are similar to the values reported for honeys from Bangladesh, ${ }^{28}$ Pakistan, ${ }^{33,37}$ Argentina and Turkey ${ }^{38}$ and Venezuela. ${ }^{39}$

The fructose contents of the honey samples analyzed in this study varied between 37.68 to $40.31 \mathrm{~g} / 100 \mathrm{~g}$ with an average of $38.94 \pm 0.40 \mathrm{~g} / 100 \mathrm{~g}$ (Table 3). The average fructose contents for the samples from the different States within the sub-region were not significantly different from each other and they all fall within the range of values reported by other scientists. ${ }^{17,40-42}$

\begin{tabular}{|c|c|c|c|c|c|c|c|}
\hline $\begin{array}{l}\text { Parameters } \\
(\mathrm{mg} / \mathrm{g})\end{array}$ & Wukro & Adigrat & Astbi & Kilteawlelo & Gantafeshum & Sinkata & Europe \\
\hline Tannins & $0.43 \pm 0.03$ & $0.5 I \pm 0.05$ & $0.54 \pm 0.04$ & $0.4 I \pm 0.06$ & $0.49 \pm 0.07$ & $0.34 \pm 0.03$ & $0.39 \pm 0.09$ \\
\hline Phlobatanins & ------- & $0.72 \pm 0.06$ & $0.65 \pm 0.09$ & ------- & $0.76 \pm 0.05$ & ------- & $0.66 \pm 0.06$ \\
\hline Flavonoids & $0.28 \pm 0.09$ & $0.30 \pm 0.06$ & $0.27 \pm 0.05$ & $0.36 \pm 0.08$ & $0.29 \pm 0.04$ & $0.33 \pm 0.07$ & $0.37 \pm 0.03$ \\
\hline Terpenoids & $0.33 \pm 0.05$ & $0.38 \pm 0.04$ & $0.4 I \pm 0.07$ & $0.39 \pm 0.09$ & ------- & $0.42 \pm 0.08$ & $0.45 \pm 0.06$ \\
\hline Glycosides & $0.3 I \pm 0.08$ & $0.33 \pm 0.08$ & $0.44 \pm 0.09$ & $0.39 \pm 0.05$ & $0.47 \pm 0.06$ & $0.37 \pm 0.07$ & -------- \\
\hline Saponins & $3.24 \pm 0.06$ & $3.22 \pm 0.07$ & $2.72 \pm 0.03$ & $3.49 \pm 0.07$ & -------- & ------- & $2.1 I \pm 0.04$ \\
\hline Alkaloids & $0.14 \pm 0.02$ & ------- & ------- & ------- & $0.18 \pm 0.07$ & $0.12 \pm 0.06$ & $0.17 \pm 0.08$ \\
\hline Flourides & $0.11 \pm 0.03$ & $0.23 \pm 0.06$ & $0.25 \pm 0.04$ & $0.21 \pm 0.03$ & -------- & ------- & $0.14 \pm 0.06$ \\
\hline *Mean \pm S.D. & & & & & & & \\
\hline
\end{tabular}

Table 2 Proximate Composition and Energy Values of Honey Samples from the six weredas in eastern zone of Tigray

\begin{tabular}{|c|c|c|c|c|c|c|}
\hline Parameter & Wukro & Adigrat & Astbi & Kilteawlaelo & Gantafeshum & Sinkata \\
\hline $\begin{array}{l}\text { Moisture } \\
(\mathrm{g} / 100 \mathrm{~g})\end{array}$ & $15.83 \pm 0.58$ & $15.83 \pm 1.26$ & $16.67 \pm 4.25$ & $17.33 \pm 2.56$ & $15.00 \pm 2.78$ & $15.33 \pm 1.53$ \\
\hline Ash (g/l00g) & $0.37 \pm 0.008$ & $0.45 \pm 0.09$ & $0.4 I \pm 0.09$ & $0.48 \pm 0.05$ & $0.47 \pm 0.11$ & $0.52 \pm 0.02$ \\
\hline Protein $(\mathrm{g} / \mathrm{l00} \mathrm{g})$ & $0.50 \pm 0.10$ & $1.04 \pm 0.04$ & $0.46 \pm 0.09$ & $0.72 \pm 0.14$ & $0.76 \pm 0.29$ & $0.55 \pm 0.22$ \\
\hline Fats $(g / 100 g)$ & $0.20 \pm 0.10$ & $0.22 \pm 0.13$ & $0.40 \pm 0.10$ & $0.35 \pm 0.09$ & $0.32 \pm 0.08$ & $0.30 \pm 0.10$ \\
\hline $\begin{array}{l}\text { Carbohydrate } \\
(\mathrm{g} / 100 \mathrm{~g})\end{array}$ & $83.09 \pm 0.54$ & $82.20 \pm 1.22$ & $82.10 \pm 4.31$ & $81.10 \pm 2.40$ & $82.33 \pm 1.76$ & $83.00 \pm 1.31$ \\
\hline Energy $(\mathrm{K} / / \mathrm{l00g})$ & $I, 407 . \mid I \pm 10.94$ & $1,405.06 \pm 18.04$ & $\mathrm{I}, 397.40 \pm 73.72$ & $1,383.23 \pm 39.09$ & $1,404.97 \pm 30.09$ & $\mathrm{I}, 4 \mathrm{I} 0.20 \pm 24.43$ \\
\hline
\end{tabular}

Values are presented as mean $\pm S D$ of three determination values significantly different from each other $(P<0.05)$. 
Table 3 Sugar Contents of Honey Samples from the sixweredas in eastern zone of Tigray

\begin{tabular}{|c|c|c|c|c|c|c|}
\hline Parameter & Wukro & Adigrat & Astbi & Kilteawlaelo & Gantafeshum & Sinkata \\
\hline Fructose $(\mathrm{g} / \mathrm{l00g})$ & $38.58 \pm 0.57$ & $39.02 \pm 0.82$ & $39.21 \pm 1.27$ & $39.06 \pm 1.13$ & $38.60 \pm 1.27$ & $39.15 \pm 0.86$ \\
\hline Glucose (g/l00g) & $31.27 \pm 6.30$ & $31.81 \pm 6.74$ & $33.36 \pm 1.99$ & $30.27 \pm 1.37$ & $31.81 \pm 1.11$ & $31.37 \pm 1.79$ \\
\hline Fructose+ Glucose(g/l00g) & $69.85 \pm 2.18$ & $70.83 \pm 7.14$ & $72.57 \pm 1.86$ & $69.34 \pm 2.35$ & $70.41 \pm 1.27$ & $70.53 \pm 1.13$ \\
\hline Reducing sugar(g/l00g) & $75.83 \pm 9.36$ & $75.26 \pm|3.7|$ & $72.85 \pm 4.75$ & $69.56 \pm 0.99$ & $69.83 \pm 3.82$ & $71.05 \pm 2.63$ \\
\hline Sucrose (g/l00g) & $1.62 \pm 0.40$ & $2.57 \pm 0.26$ & $\mathrm{I} .0 \mathrm{I} \pm 0.42$ & $2.54 \pm 0.97$ & $\mathrm{I} .0 \mathrm{I} \pm 0.33$ & $2.46 \pm 0.27$ \\
\hline Fructose/Glucose Ratio & $1.23 \pm 0.05$ & $1.26 \pm 0.23$ & $1.18 \pm 0.10$ & $1.29 \pm 0.04$ & $1.21 \pm 0.07$ & $1.25 \pm 0.10$ \\
\hline Glucose/water Ratio & $1.98 \pm 0.11$ & $2.04 \pm 0.6 I$ & $2.09 \pm 0.58$ & $1.77 \pm 0.26$ & $2.16 \pm 0.34$ & $2.05 \pm 0.09$ \\
\hline
\end{tabular}

In a similar manner, the glucose contents of the honey samples obtained from the various locations in the different States of the subregion were not significantly different from each other. The glucose contents of the samples which varied from 27.25 to $39.56 \mathrm{~g} / 100 \mathrm{~g}$ with an average of $31.65 \pm 2.79 \mathrm{~g} / 100 \mathrm{~g}$ were significantly $(\mathrm{P}<0.05)$ lower than the fructose contents. This observation shows that fructose is the major sugar in all the samples analyzed and, it is in agreement with the earlier observation of White and Doner. ${ }^{17}$ Fructose and glucose are the dominant sugar types in honeys, which although no limits have been fixed for their individual values, their sum (Fructose glucose) has been fixed at a value of $\geq 60 \mathrm{~g} / 100 \mathrm{~g}$ as one of the requirements of the international standard for honey established by Codex Alimentarius Commission. ${ }^{43,44}$ The sum of fructose and glucose for the honey samples, used in this study, indicates that samples have their values corresponding to the limit required by the international norms; i.e., $60 \mathrm{~g} / 100 \mathrm{~g}$ and above. According to White and Doner ${ }^{17}$ the dominance of fructose over glucose is one way in which honey differs from commercial invert sugar. Generally, the sugar spectrum of honey depends upon the sugars present in the nectar and the enzymes present in the bee and nectar. ${ }^{17,25,33}$ Fructose and glucose constitute the primary sugars in all honey samples, and in honey of good quality the fructose content should exceed that of glucose..$^{33}$

In addition to the sum of fructose and glucose, other important factors that relate to honey quality include the fructose/glucose ratio and glucose/water ratio. In this study, the fructose/glucose ratio and glucose/water ratio fall in the range of 1.00 to 1.45 and 1.59 to 2.75 with average values of $1.24 \pm 0.10$ and $2.01 \pm 0.35$, respectively. Fructose/ glucose ratio indicates the ability of honey to crystallize. White and Doner ${ }^{17}$ stated that even though honey has less glucose than fructose, it is the glucose that crystallizes when honey granulates because it is less soluble in water than fructose. When the fructose/glucose ratio is high, honey remains liquid. Honey crystallization is slower when the fructose/glucose ratio is more than 1.3 and it is faster when the ratio is below 1.0. ${ }^{41}$ However, because honey contains others sugars (sucrose, maltose, turanose, etc.) and insoluble substances (like dextrin, colloids, etc.) which can influence the crystallization process, the glucose/water $(\mathrm{G} / \mathrm{W})$ ratio is considered more appropriate than the fructose/glucose $(\mathrm{F} / \mathrm{G})$ ratio for the prediction of honey crystallization. ${ }^{45}$ It has been stated that when the glucose/water ratio is $<1.3$ honey crystallization is very slow or even zero, and it is complete and rapid when the ratio is $>2.0 .{ }^{41}$ Glucose, which is a major sugar in honey, can spontaneously crystallize from honey solutions in the form of its monohydrate. ${ }^{17}$ This sometimes occurs when the moisture level in honey is allowed to drop below a certain level; i.e., when the moisture content is very low. It was stated earlier on that honey samples with $(\mathrm{G} / \mathrm{W})$ ratio of $<1.7$ are
Considered non-granulating while samples with ratios of $\geq 2.1$ predicts rapid granulation. Also, according to Manikis et al., ${ }^{16}$ while glucose levels is a useful indicator of honey granulation, the G/W ratio appears to be one of the most effective indicator for predicting granulation tendencies in honey samples. Thus, G/W ratio may be used both to predict and control granulation tendencies in honeys. ${ }^{46}$

The apparent sucrose contents of the honey samples studied were in the range of 0.53 to 3.29 with an average of $1.84 \pm 0.79 \mathrm{~g} / 100 \mathrm{~g}$. The values obtained for sucrose contents of the honey samples were all within the limits of international standards that are the international norm established by the Codex Alimentarius Commission requirement that a good quality honey should not contain more than $5 \mathrm{~g} / 100 \mathrm{~g}$ sucrose. According to White and Doner ${ }^{17}$ even though honey contains an active sucrose splitting enzyme (sucrase, glucosidase), the sucrose level in honey never reaches zero. The sucrose contents obtained in this investigation are within the range of values reported for Argentine and Turkish, ${ }^{38}$ Venezuelan, ${ }^{39}$ American, ${ }^{17}$ Algerian, ${ }^{42}$ Pakistani ${ }^{37}$ and Spanish $^{30}$ honeys.

\section{Conclusion}

The values of quality parameters for all the honey samples studied coincide with those specified by the international honey regulations. The honey samples are also rich in phenolic and vitamin $\mathrm{C}$ contents which confer good antioxidant properties in honey All these verities of honey are easily available and contains nutrients especially as energy provider sugar, vitamin $\mathrm{C}$ and phenolic compounds which having medicinal importance. In branded honey the concentration and quantity of ash, $\mathrm{pH}$, moisture, total acidity, electrical conductivity and total sugars contents are more as compare to unbranded honey. The phenolic and antioxidant compound concentration in branded honey is also more than unbranded honey. But as a whole these available honey can be utilized in various food products and herbal formulations.

\section{Acknowledgements}

None.

\section{Conflict of interest}

The author declares no conflict of interest.

\section{References}

1. Apiculture research strategy and development program (ARSD) 200. Approaches, methods, and processes for innovative apiculture development. Experiences from Ada'a-Liben. 
2. Matei N, Birghila $\mathrm{S}$, Dobrinas $\mathrm{S}$, et al. Determination of $\mathrm{C}$ vitamin and some essential trace elements $(\mathrm{Ni}, \mathrm{Mn}, \mathrm{Fe}, \mathrm{Cr})$ in bee products. Acta Chi mica Slovania. 2004;51:169-175.

3. Ayansola A, Banjo AD. Physico-chemical "Evaluation of the authenticity of honey marketed in southwestern Nigeria". J Basic Appl Sci Res. 2011;1(12):3339-3344.

4. Doner LW. The sugars of honey - - a review. J Sci Food Agric. 1977;28(5):443-456.

5. Bogdanov S, Jurendic T, Sieber R, et al. Honey for nutrition and health: a review. J Am Coll Nutr. 2008;27(6):677-689.

6. Sanz ML, Sanzand J, Martinez CL. Presence of some cyclitols in honey. J Food Chem. 2004;84:133-135.

7. Ayalew K. Honey bee flora and ecology in Tigray. In: Bee Behaviour and Comparison of Hive Efficiency in Tigray. Ethiopia: BoANR (Bureau of Agriculture and Natural Resources) Tigray; 2001

8. Bureau of Agriculture and Natural resources Development. Tigray livestock development action program. 1997. p. 4-6.

9. Cartland B. The magic of honey. London, UK: Corgi Books; 1970 p.

10. Med Food 7: 67-78.

11. Terrab A, Recamales AF, Hernanz D, et al. Food Chem. 2004;88:537.

12. Atrouse OM, Oran SA, Al Abbadi SY. Chemical analysis and identification of pollen grains from different Jordanian honey samples. J Food Sci Technol. 2004;39(4):413-417.

13. Bureau of Agriculture and Natural resource Development. Personal communications (Teklay). Tigray livestock development action program; 2008 .

14. Tchoumboue J, Awah-Ndukum J, Fonteh FA, et al. Physico-chemical and microbiological characteristics of honey from Sudano-guinean zone of west Cameroon. Afri J of Biotechnol. 2007;6 (7):908-913.

15. Lachman J, Hejtmankova A, Sykora J, et al. Contents of major phenolic and flavanoid antioxidants in selected Czech honey. Czech J Food Sci. 2010;28(5):412-426.

16. Meda A, Lamien CE, Romito M, et al. Determination of the total phenolic, flavonoid and proline contents in Burkina Fasan honey, as well as their radical scavenging activity. Food Chemistry. 2005;91:571-577.

17. Makawi SZA, Gadkariem EA, Ayoub SMH. Determination of antioxidan flavonoids in Sudanese honey samples by Solid Phase Extraction and High Performance Liquid Chromatography. E J Chemistry. 2009;6:429-437.

18. Akiyama H, Fujii K, Yamasaki O, et al. Official Methods of Analysis of the Association of Analytical Chemists. 15th ed. AOAC, Washington, USA DC; 1990.

19. Kaskoniene V, Maruska A, Kornysova O, et al. Quantitative and qualitative determination of phenolic compounds in honey. Chemine Technologi jaNr. 2009;3:74-80.

20. Kesic A, Mazalovic M, Crnkic A, et al. 2009.

21. Gebreegziabher G, Gebrehiwotand T, Etsay K. "Physiochemical characteristics of honey obtained from traditional and modern hive production systems in Tigray region, northern Ethiopia". Momona Ethiopian Journal of Science. 2013;5 (1):115-128.

22. Gheldof N, Wang XH, Engeseth NJ. Identification and quantification of antioxidant components of honeys from various floral sources. $J$ Agric Food Chem. 2002;50(21):5870-5877.

23. Al-Ghannam SM, Al- Olyan AM. High Performance Liquid Chromatographic method for the determination of nicardipine in pure, pharmaceutical preparations and plasma and its application to pharmacokinetics in humans. Electronic Journal of Chemistry. 2009;6:429-437.

24. Bogdanov S, Martin P. Mitteilungen aus den Gebiete der lebensmitteluntersuchung und hygiene. Honey authenticity. 2003;93:232254

25. Harmonised Methods of the International Honey Commission. International Honey Commission; 2009. p. 1-63.

26. Ouchemoukh S, Louaileche H, Schweitzer P. Raw Mellefiori honey is packed full of antioxidants. Food Chemistry. 2007;97:217.

27. Subramanian R, Hebbar HU, Rastogi NK. Processing of honey: A review. Interl J Food Properties. 2007;10 (1):127-143.

28. Tan ST, Holand PT, Wilkins AL, et al. Extractives from New Zealand honeys. 1 White clover, manuka and kanuka unifloral honeys. Journal of Agricultural and Food Chemistry. 1988;36(3):453-460.

29. Shi J, Arunasalam K, Yeung D, et al. Saponins from edible legumes: chemistry, processing and health benefits. J Med Food. 2004;7(1):67-78.

30. Terrab A, Gonzalez AG, Diez MJ, et al. Characterization of Moroccan unifloral honeys using multivariate analysis. Eur Food Res and Technol. 2003;218(1):88-95.

31. Terrab A, Recamales AF, Hernandez D, et al. Characterization of Spanish thyme honeys by their pytochemical characteristics and mineral contents. Food Chem. 2004;88:537-542.

32. Trease GE, Evans MC. Pharmacognosy. 14th ed. New Delhi, India: Elsevier; 2005.

33. Turhan K. J Fresen Environ Bull. 2007;16:459.

34. Siddiqui IR. The sugars of honey. Advances in Carbohydrate Chemistry and Biochemistry. 1970;25:285-309.

35. Singh N, Kuar Bath P. Quality evaluation of different types of Indian honey. Food Chemistry. 1997;58:129-133.

36. Zafar A, Safdar M, Siddiqui N, et al. Chemical analysis and sensory evaluation of branded honey collected from Islamabad and Rawalpindi market. J Agric Res. 2008;21(1-4):86-91.

37. Nandaa V, Sarkara BC, Sharmaa HK, et al. J Food Comp Anal. 2003;16:613.

38. Lawal RA, Lawal AK, Adekalu JB. "Physicochemi - cal studies on adulteration of honey in Nigeria". Pakistan J Biological Sciences. 2009;12(15):1080-1084.

39. Balandrin MJ, Klocke JA, Bajaj YPS. Berlin. Springer - vela Medicinal and aromatic plants. Biotechnol Agri Forest. 1988;24(4):1-36.

40. Vit P, Rodríguez-Malaver A, Roubik DW, et al. Expanded parameters to assess the quality of honey from Venezuelan bees (Apis mellifera). Journal of ApiProduct and ApiMedical Science. 2009;1(3):72-81.

41. Blassa M, Candracci M, Accorsi A, et al. 2006.

42. Oboh G. Effect of blanching on the antioxidant property of some tropical green leafy vegetables. Technology. 2005;38:513-517.

43. QSAE, Quality Standard Authority of Ethiopia, Ethiopian "Standard Specifications for Honey", ES1202; 2005.

44. Cavia MM, Fernández - Muiño MA, Alonso-Torre SR, et al. An attempt to establish reliable "Best Before" dates for honeys originating in both continental and oceanic climates. Apiacta. 2006;41:86-98.

45. Draft revised standard for standard for honey (at step 10 of the Codex procedure). Codex Alimentations Alinorm, 01/25. Czech Journal of Food Science. 2001;28:412-426. 
46. Iwatsuki K. Antibacterial action of several tannins against Staphylococcus aureus. J Anti Chemo. 2001;48(4):487-491.
47. Manikis I, Thrasivoulou A. Relation of physicochemical characteristics of honey and the crystallization sensitive parameters. Apiacta. 2001;3:106112 